\title{
Crypto-currencies, Speculation and the Evolution of Monetary Systems
}

\author{
Andres Solimano* \\ CENTRO INTERNACIONAL DE GLOBALIZACIÓN Y DESARROLLO - CIGLOB
}

\begin{abstract}
The development of new digital technologies in the areas of cryptography, distributed ledgers and mobile phones is affecting the way money is used for economic transactions. Electronic payments systems are rapidly replacing the use of cash. New powerful distributed ledger technologies, operated on a peer-to-peer decentralized basis is leading to the rapid expansion of digital money, with bitcoin being the most prominent digital currency (although there are more than one-thousand different crypto-currencies).
\end{abstract}

Keywords: Digital technologies, electronic payments, digital money, bitcoin

\section{RESUMEN}

El desarrollo de nuevas tecnologías digitales en las áreas de criptografía, libros de contabilidad distribuidos y teléfonos móviles está afectando la forma en que se utiliza el dinero para las transacciones económicas. Los sistemas de pagos electrónicos están reemplazando rápidamente el uso del efectivo. Las nuevas y potentes tecnologías de libro mayor distribuido, operadas en una base descentralizada de igual a igual, están llevando a la rápida expansión del dinero digital, siendo Bitcoin la moneda digital más prominente (aunque hay más de mil crypto-monedas diferentes).

Palabras Clave: Tecnologías digitales, pagos electrónicos, dinero digital, bitcoin.

*asolimano@gmail.com 


\section{INTRODUCTION}

he development of new digital technologies in the areas of cryptography, distributed ledgers and mobile phones is affecting the way money is used for economic transactions. Electronic payments systems are rapidly replacing the use of cash. New powerful distributed ledger technologies, operated on a peer-to-peer decentralized basis is leading to the rapid expansion of digital money, with bitcoin being the most prominent digital currency (although there are more than one-thousand different crypto-currencies). Software protocols that underpin the issuance and circulation of digital currencies do not require a centralized validation, by commercial banks, financial agencies and central banks, of transactions to avoid the critical problem of doublespending a currency unit. Therefore, Bitcoin can undermine the power of entrenched financial intermediaries that charge a commercial fee, producing handsome profits. Beyond that, it has the potential to contest the power of central banks to conduct monetary policy. Digital currencies are appealing in that affect the entrenched world of high finance and central banking, two actors with a share of responsibility, for action or omission, in the making of costly financial crises around the world, the most severe taking place in 2008-09.

The inception of new monies is not new in financial history. Commodity-based systems that ruled for several centuries were replaced by fiat money only in the 20th century. The proliferation of central banks, in its modern guise, is also a feature of the 20th century. The emergence of Bitcoin offers interesting potential for establishing global currencies with lower cost-border transaction costs. The new technology embedded in bitcoin seems to have been appreciated by the market as its price skyrocketed in recent years (particularly in the last quarter of 2017). This poses intriguing questions for asset-price theory, being bitcoin an intrinsically worthless asset (e.g a computer entry). In turn, the trajectory of bitcoin prices resembles other speculative bubbles in financial history. Crypto-currency exchanges are spreading fast around the world and the market capitalization value of digital currencies already exceed the GDP of small-middle 
size economies. Digital currencies are already accepted in many stores and companies. On the other hand, the emergence of digital currencies poses challenges for existing regulatory frameworks in the financial field and the control of illegal activities.

The historical record on the evolution of money shows that structural transformations in monetary regimes rest on an array of factors such as the cost of generating money, ability to perform the functions of mean of exchange, unit of account and store of value, the structural risks of deflation or, alternatively, the risk of inflation, contribution to financial stability, the ability to have a lender of last resort and the allocation of seigniorage.

This paper provides an overview of critical issues behind the emergence of crypto-currencies and its interactions with assetpricing (bubble-formation) and the evolution of monetary systems. Section 2 provides basic information on the computational ledger mechanism (DLT technology), blockchains and peer-to peer transactions. Section 3 presents empirical data on the behavior of bitcoin prices in the period 2010-2018, discussing its sharp escalation in value along with its ups and downs; section 4 illustrates various historical and more recent episodes of bubble formation and prickling that can shed some light on the observed behavior of bitcoin prices. Section 5 asks the question "Is bitcoin money?"; it compares token-based versus credit-based money systems (double -entry) and the extent to which bitcoin can perform the three classic function of money in light of its currently high price, its variability and the current density of the market for bitcoins. Section 6 compares digital currencies with fiat money and commodity based systems using the criteria mentioned above. So far, bitcoin seems to be an eclectic mix of commodity-based and fiat based monetary systems. Section 7 concludes.

\section{THE DIGITAL INFRASTRUCTURE OF CRYPTO-CURRENCIES:} DISTRIBUTED LEDGER TECHNOLOGIES AND BLOCKCHAINS

The name crypto-currency derives from embedded encryption techniques used in the generation of units of currency ${ }^{1}$. Encryption prevents forgery that undermines trust. Of course, hackers could 
try to break encryptions and disrupt the network but this has not happened yet at any substantial scale to disrupt Bitcoin. The bitcoin rests on a supporting digital infrastructure structured around a ledger, say a list of transactions verifiable by the different members of a computing network. Transactions are registered sequentially, are irreversible and anonymous. They can not be altered once validated in the networks by the "miners". Every 10 minutes, approximately, a set of verified transactions - a block- is added to the blockchain. This verification process is called mining and requires solving a mathematical puzzle based on random number allocations. Miners performing this task are rewarded by crediting them with cryptocurrencies (they can also charge a fee). This creation of bitcoin provides economic incentives for miners to update the network and also serve the function of pumping currency into the economy. In Bitcoin (capital letter denotes the system and lowercase letter the currency) people hold "electronic wallets" that allow them to store digital currency in a secure way and undertake transactions. It is the equivalent of an account in traditional monetary systems, although wallets are not structured around a double-entry method. ${ }^{2}$ The digital mechanism that underpins digital money was presented in a paper written by a programmer signing under the name of Satoshi Nakamoto entitled "Bitcoin: A Peer to Peer Electronic Cash system" (Nakamoto, 2009). The three main properties set-out in Nakamoto's paper are: (a) decentralization in the validation of transactions, (no need of a central authority or external agency to very exchanges), (b) encryption and proof-of -work property and (c) all transactions recorded in the ledger can not be erased, altered or undone. The system provides a cryptographically secured database that satisfies anonymity, irreversibility and peer-to peer properties.

A viable monetary arrangement has to properly solve the problem of "double-spending". Double-spending occurs anytime the same unit of currency is simultaneously used in more than one transaction, giving rise to fraudulent practices and forgery. Currencies have to ensure credibility between a payer (that delivers money) and a payee (that receives money). The degree of centralization in money- 
production and money-use is another consideration. Notes and coins issued by central banks are provided in a centralized way but used in decentralized fashion (peer to peer). ${ }^{3}$ Cash allows rapid verification for retail transactions and demand-deposits and electronic transfers enable larger-size transactions but often requires some verification by a "trusted third party". The great novelty of digital currencies is the ability to solve the problem of double spending in a decentralized, peer-to peer, basis with the assistance of a computational system of distributed ledger technology (DLT) bypassing (remunerated) "third party trust".

Bitcoin, the most important crypto-currency nowadays accounts for 38 percent of market transactions and 47 percent of the value of transactions in crypto-currencies (IMF, 2018). As of 2018, Bitcoin represents around 39 percent of total transactions and 47 percent of the market capitalization value of crypto-currencies (IMF, 2018). According to the International Monetary Fund (IMF,2018) the total turnover of crypto-currencies represents nowadays close to 4 percent the balance sheets of the for main central banks. A few years ago this share was virtually zero.

In contrast with national (public) monetary systems run by central banks, in a digital currency system such as Bitcoin, the seigniorage is appropriated privately and distributed to chain users. According to the protocol set at the outset, the amount of bitcoins produced in 10-minute intervals is halved (reduced by 50 percent) every four-years. The total amount of bitcoins in the world economy was set to reach no more than 21 million by year 2140 although 98 percent is expected to be completed by 2030 (see www.bitcoin.org).

There is a democratic element in the new technology that underpins Bitcoin: anybody can join the blockchain as it is an opensource process. Those who join the network have full access to the database, can read existing information and add new one, subject to certain shared protocols. There are also blockchains in which accessing and writing in the blockchain requires authorization. The blockchain reduce the transaction costs of using a digital currency, an appealing feature of digital money. Having more consumers and 
merchants doing transaction with digital money (from shopkeepers, to merchants, providers of services and others) promotes exchange, efficiency and wealth creation in the economy through network externality effects. There are no restrictions on the goods and services that can be traded with crypto-currencies and anonymity is guaranteed that is valued in a world of growing privacy concerns.

Critics and skeptics of crypto-currencies point to the potential of use of crypto-currencies for illegal activities such as drug-dealing and the funding of terrorism. A study (Foley, Karlsen and Putnins, 2018) estimates that near 25 percent of the crypto-currency users have been engaged in trade in illicit activities. In the United States, a few years ago, the FBI closed a website called "The Silk Road" that traded drugs using crypto currencies. Crackdowns on digital currencies have also taken place in China, Russia, Bolivia and other countries. However, this argument against the use of digital currencies may be feeble if we consider that most of drug trade is routinely conducted in US dollars and other major traditional currencies that are legal tenders in their respective jurisdictions. Another issue is the high energy-requirements (electricity) and computer computer power involved in running the DLT and manage multiple transactions involving digital currencies. Mining can be a quite energy- consuming process.

3. THE PRICE OF BITCOIN: SHARP REVALUATIONS, HIGH VOLATILITY AND BUBBLES

A paradox in the introduction of Bitcoin is that being an intrinsically worthless computer entry, its price has increased sharply in a few years. In fact, it went -up from less than one-dollar per bitcoin in 2010 to a peak of U\$ 19,500 in December of 2017, followed by a decline to around U\$ 8,500 in late July 2018. Its price trajectory, however, has been subject to substantial volatility with sharp ups and downs. It is apparent, that the rise in the demand for Bitcoins stem from from the expectations of its usefulness as a currency that could be widely adopted in economic transactions worldwide. It also may be a reflection of the potential assigned by the market to 
the DLT-based technology. The British economist John Maynard Keynes identified three main motives in the demand for money: transaction, precaution and speculation. Thus the increase in the demand and price of bitcoins a "transaction motive" and a speculative demand as an asset.

Figure i. Price of bitcoin (us dollars, august 20 io - July 20I8)

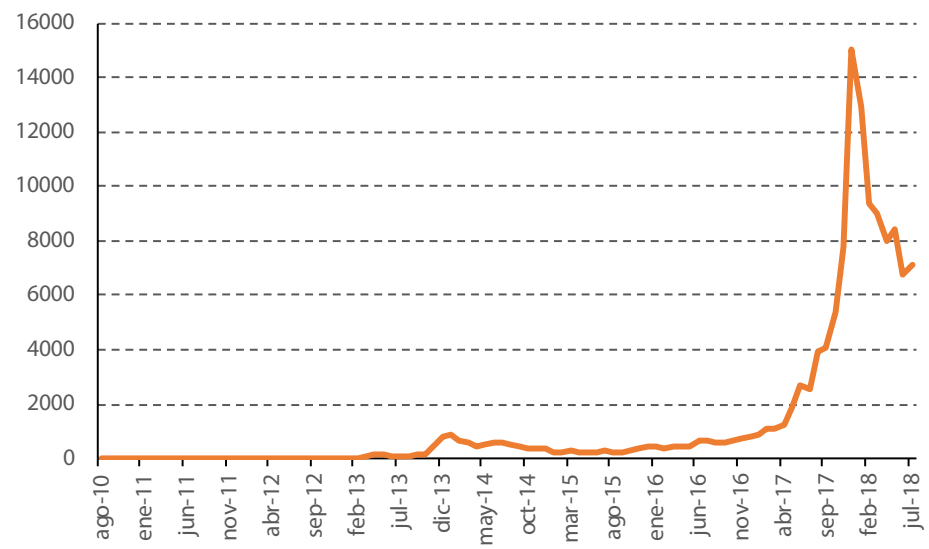

Source: Own elaboration based on data from CoinDesk

There have been several spells of price increases: April- July 2011, July-December 2013, May-December 2017 accompanied by "price corrections" (declines) in July-November 2011, January 2014September 2015 and January-June 2018 (see figure 2a-d). 
Figure 2 A) PRICE OF BitCOIN (US DOLlar, AUGUST 20 I O - DECEMBER 2OII)

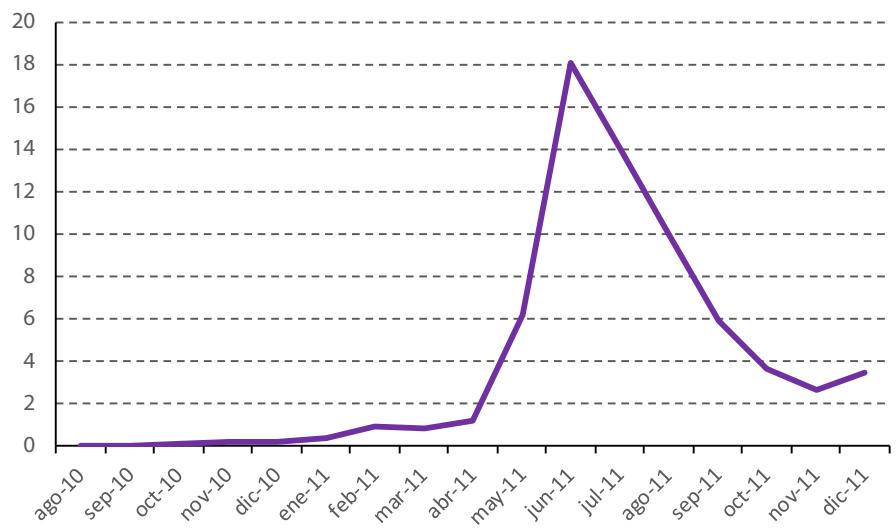

Source: Own elaboration based on data from CoinDesk

Figure 2 B) PRICE OF BITCOIN (US DOLLAR, JANUARY 20 I 2- DECEMBER 2OI3)

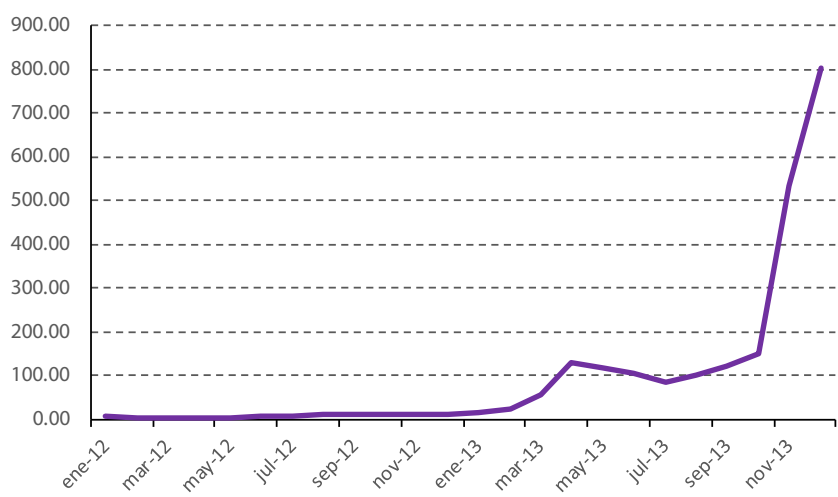

Source: Own elaboration based on data from CoinDesk 
Figure 2 C) PRICE OF BitCoin (US DOLlar, JANUARY 2014 DECEMBER 2OI5)

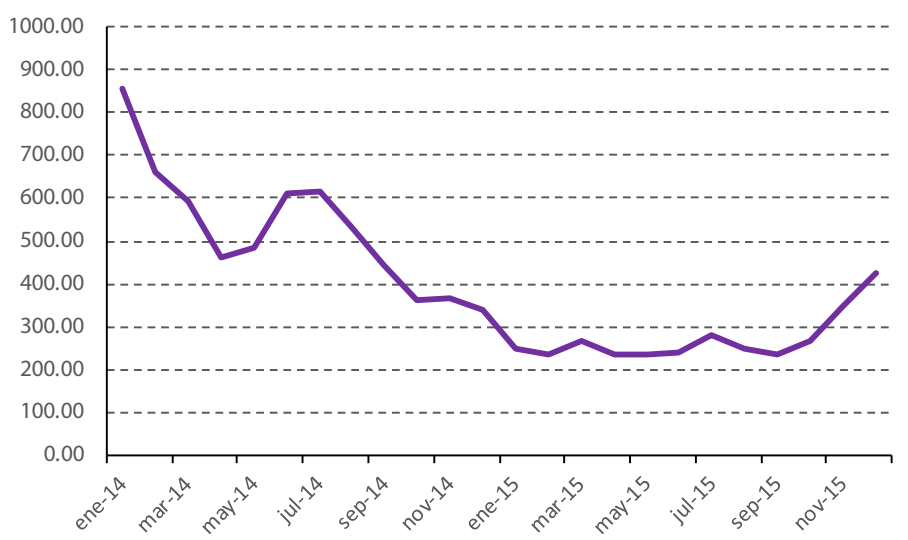

Source: Own elaboration based on data from CoinDesk

Figure 2 D) PRICE OF BITCOIN (US DOLLAR, JANUARY 20 I6 - JULY 20I8)

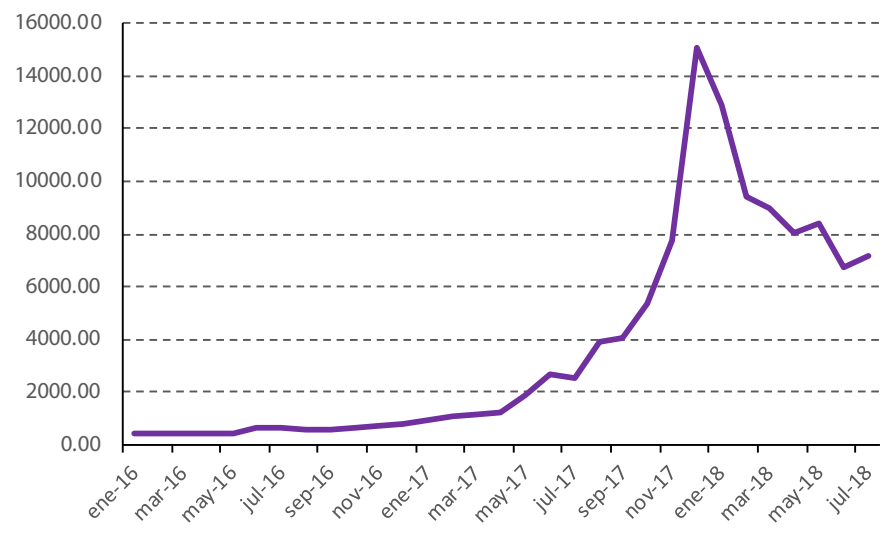

Source: Own elaboration based on data from CoinDesk

The sharp escalation, accompanied by volatility, in the price of Bitcoin has been remarkable. In the period August 2010 to December 2011 the average price of bitcoin was U\$ 4 dollars, 
increasing to U\$ 98.2 in the period January 2012- December 2013, U\$ 400 in January 2014 to December 2015 and U\$ 3,746.6 in January 2016- July 2018 (see table 1). The standard deviation of prices increases with the mean and the coefficient of variation has exceeded the value of one in most periods presented in table 1.

Table 1. Descriptive statistics in the price of bitcoin: Mean, STANDARD DEVIATION AND COEFFICIENT OF VARIATION (AUGUST 2OIO - JULY 2OI8)

\begin{tabular}{|c|c|c|c|}
\hline Period & Mean & $\begin{array}{c}\text { Standard } \\
\text { Deviation }\end{array}$ & $\begin{array}{c}\text { Coefficient of } \\
\text { variation }\end{array}$ \\
\hline August 2010 - December 2011 & 4.01 & 5.36 & 1.34 \\
\hline January 2012 - December 2013 & 98.20 & 186.71 & 1.90 \\
\hline January 2014 - December 2015 & 399.59 & 171.61 & 0.43 \\
\hline January 2016 - July 2018 & 3743.57 & 4113.12 & 1.10 \\
\hline
\end{tabular}

The monthly troughs and peaks for every year since 2011 to 2018 are shown in table 2 .

TABle 2. MONTHLY PEAKS AND TROUGHS IN THE PRICE OF BITCOIN (Current us dollars, 20I I-20I8)

\begin{tabular}{|c|c|c|c|c|}
\hline & Trough (USD, \$) & Peak (USD, \$) & $\begin{array}{c}\text { Variation } \\
\text { trough } \\
\text { to peak } \\
\text { (increase, \%) }\end{array}$ & $\begin{array}{c}\text { Variation } \\
\text { peak to } \\
\text { trough } \\
\text { (decline, \%) }\end{array}$ \\
\hline 2011 & $\$ 0.37(1)$ & $\$ 18.07(6)$ & 4791.68 & - \\
\hline 2012 & $\$ 4.90(3)$ & $\$ 13.36(12)$ & 172.55 & - \\
\hline 2013 & $\$ 15.61(1)$ & $\$ 801.74(12)$ & $5,037.00$ & - \\
\hline 2014 & $\$ 340.50(12)$ & $\$ 857.18(1)$ & - & -60.28 \\
\hline 2015 & $\$ 233.50(9)$ & $\$ 424.52(12)$ & 81.81 & - \\
\hline 2016 & $\$ 403.49(2)$ & $\$ 824.78(12)$ & 104.41 & - \\
\hline 2017 & $\$ 911.26(1)$ & $\$ 15,065.28(12)$ & 1553.24 & - \\
\hline 2018 & $\$ 6,769.70(6)$ & $\$ 12,926.66(1)$ & - & -47.63 \\
\hline
\end{tabular}

Source: Own elaboration based on data from CoinDesk 


\section{Other price bubbles}

Financial history contains various episodes of very rapid increase in the price of assets that can hardly be explained by "fundamentals". 4 What is the fundamental value of bitcoin? One possible answer is the present value of economizing transaction costs relative to other, traditional, currencies. Another interpretation is of a price bubble. Bubbles, are often surrounded by over-optimistic expectations and euphoria and can affect stocks, real estate, gold, artwork, land, foreign exchange, oil and metals. Historical examples include the Tulip-mania in Netherlands in 1636-37, the South-sea and Mississippi bubbles in 1719-20, Ponzi coupons in the 1920s, sharp stock price increases in the late 1920s. More recent cases are the boom in gold prices in the 1970s, the dot-com bubble of the late 1990s, home price booms in the 2000s in advanced capitalist economies prior to the crisis of 2008-09 and other speculative episodes (see figures 3 to 6). Price bubbles can arise in a diversity of contexts: the discovery of a valuable natural resource, a new export market, a new technology or transportation mean such the railways in the 19th century. The IT revolution led to the dot.com bubble in the late 1990s. The distributed ledger technology is another main innovation. Besides being interesting financial curiosities, there are important real world consequences of the rise and subsequent collapse of a bubble: by inflating asset prices above fundamentals values, they invite over-investment in activities with transitory high returns creating an excess supply that becomes evident when the bubble prickles. Bubbles often lead to misallocation of resources in the economy on the supply side and create wealth effects (demand side) leading to high consumption and over-indebtedness that could not be sustained over time (Solimano, 2017). The crypto-bubble seems to be a recent example of these dynamics. ${ }^{5}$ 
Figure 3. Price bubbles
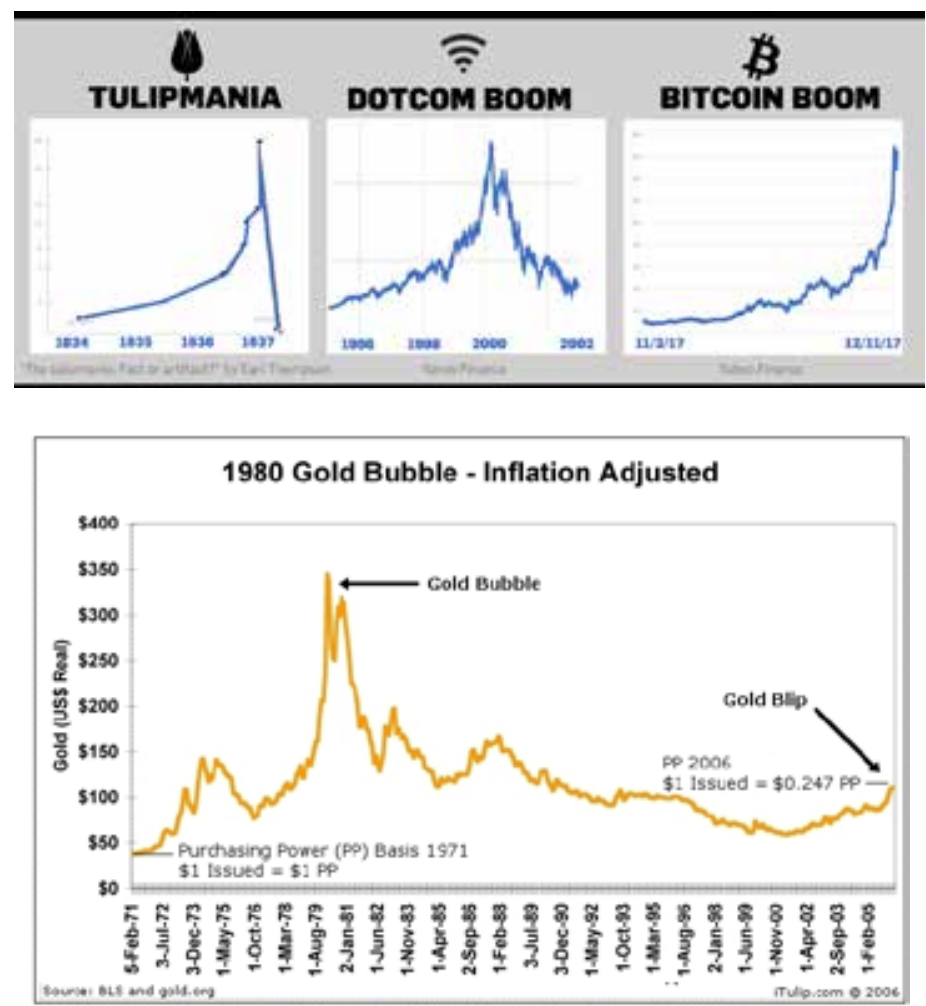

Figure 5 u.S. Stock MARKet PRice index (NASDAQ)

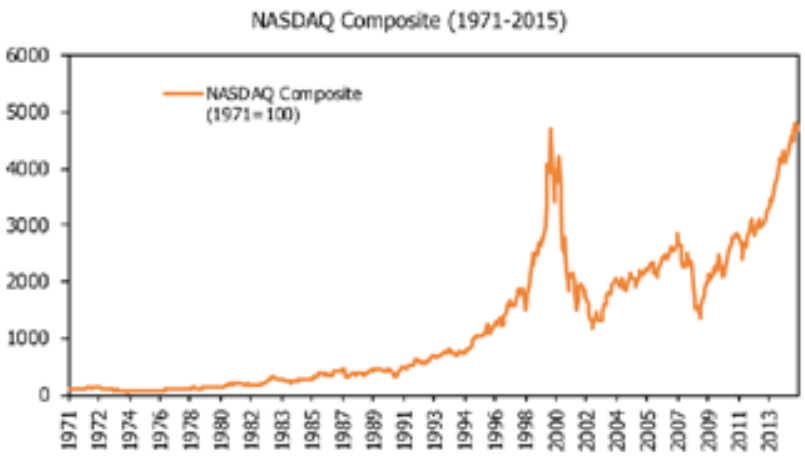

Source: Yahool Finance, 2015. 
Figure 6. Home PRICES IN JAPAN IN THE $20^{\mathrm{TH}}$ CENTURy.

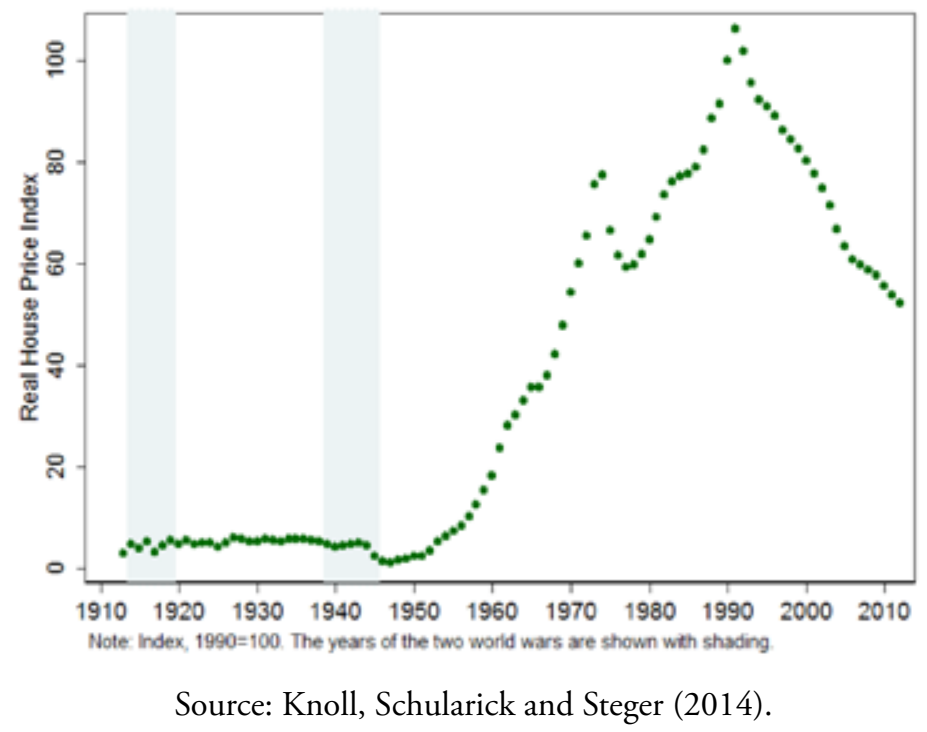

\section{IS BITCOIN MONEY?}

The answer to this question is also complex. Digital currencies are not a liability of any institution such as commercial bank or central bank. Bitcoin is not a case of private money issued by a commercial bank. Its software can be download for free. It is not a project inspired in capitalist principles of profit-maximization, although of course many holders of bitcoin that bought them at low initial prices have made a lot of money (some others that bought later have probably lost money, too). Furthermore, there is no legal commercial entity that created Bitcoin. Neither its founder, Mr. Nakamoto, nor other programmers or entrepreneurs claim ownership of the blockchain, restricting its use only to those who make a payment.

Bitcoin has features of "token-based" monetary systems in which cash is exchanged for goods, services, assets. This is different from "credit-based" money structured around a asset-liability structure lying behind individual accounts. ${ }^{6}$ Bitcoin shares peer-to peer features with fiat money (notes and coins) but differs from demand 
deposits in that it does not require centralized verification (third party trust) for validating transfers between a payer and a payee. The supply of Bitcoin follows a pre-determined rate of growth (not necessarily constant) but it was set in a total number. In a sense, it resembles Milton Friedman's famous rule of a predetermined rate of growth of the money supply, claiming that this rule would ensure low and stable inflation in the price of goods and services (few central banks adopted it). Nonetheless, the Friedman's rule entailed money growing at a constant (fixed) rate while in Bitcoin the rate of growth is non-linear and decreasing over time (in order to be consistent with a given maximum supply defined in level terms, 21 million). Of course, Friedman envisaged his proposed monetary rule to be adopted by the central bank rather than being set by a computing algorithm launched by anonymous programmers as in the case of digital currencies.

Bitcoin, Ethereum,Ripple, Litecoin, Monero and other cryptocurrencies are electronic-money but not all forms of electronic money constitute a digital currency. Traditional E-money such as creditcards, Paypal enable the clearing of transactions and the settling of accounts in a centralized fashion, engendering monopolistic tendencies with financial intermediaries having the ability to extract fees and commissions from market participants.

For an asset to be called "money" it has to perform the functions of: (i) mean of payments, (b) unit of account and (c) store of value. The role of Bitcoin as a mean of payments has grown over time as its availability to the public has increased from licensed exchanges in a variety of countries. In addition, the number of stores, companies and service providers that accept Bitcoins as payments has also raised. One is a supply side factor and the other a demand-side condition. Nevertheless, digital money is still far from replacing the dominance of fiat-money as mean of payments enjoying legal tender status. The bitcoin market still lacks density.

The unit of account function of bitcoin is hampered by the fact that its price is too high for retail transactions and requires big divisibility. In fact, if the exchange rate between bitcoins and US 
dollars is say $U \$ 7,500$ and the price of a pack of cigarettes is 4 dollars, its equivalent price is 0.00053 bitcoins. This simple example illustrates that quoting bitcoins prices of retail goods often entails a large number of left hand-side zero, which, in practice, makes it difficult for consumers to compare prices across a range of goods and services. This feature can be expected to discourage, for a while, the use of bitcoin as a unit of account and mean of payments. Regarding the store of value function, the high volatility in bitcoins prices is also a deterrent, for the time being, for a stable store of value. However, this feature may change over time if the price of this digital currency moves to more stable plateaus.

\section{BITCOIN AND OTHER MONETARY SYSTEMS COMPARED}

The bitcoin shares both similarities and differences with fiat-money systems (paper currency backed by a central bank or monetary base $)^{7}$, commodity-money (gold bullion, gold coins of a given fineness and weight) and commodity-based money systems (e.g the gold standard), see table $3 .^{8}$

A similarity between Bitcoin and commodity-based money is that currency is not produced by central banks. In fact, the supply of gold that underpinned the gold standard came from mineral deposits sitting underneath. In other words, the stock of money is anchored by natural resource constraints, which ensures that money can not be printed at the will of monetary authorities or governments. However, the popular notion that commodity-based monetary systems made impossible the manipulation of the money supply by governments is a bit of a myth. The historical record from at least 1200 shows that governments could, indeed, debase metallic money by reducing their fineness and weight (content of gold or silver), see Redish, 1993. ${ }^{9}$ Thus, government in a commoditymoney scheme (coins of gold and silver used as legal tender) did depreciate the value of the currency, but probably at a reduced scale compared with a fiat money system.

Depreciating a commodity-currency had a certain rationale. This was to allow ruling monarchs enjoying the monopoly of the mint 
(facilities for coining metal currency) to increase their collection of seigniorage. This practice was exacerbated at the time of war when the survival of the state was at risk and the collection of more conventional taxes (land tax, excise taxes) was difficult.

As said, the supply of bitcoin is set by an algorithm completely independent from a monetary authority or other existing financial institution. In this sense, bitcoin looks as a commodity-based money but, unlike silver or gold, without intrinsic value. In contrast, gold or silver can be used for producing jewelry, watches, dental parts, decorative furniture and other consumption and production uses, therefore having an intrinsic value. Bitcoin constitutes a somewhat "eclectic currency" as it shares elements of both commodity-based and fiat-money systems. ${ }^{10}$ On one hand, it is worthless like fiat money but its supply is given like commodity-based monetary systems (table 3). In addition, it shares with commodity-based systems three features: (a) deflationary tendencies, (b) difficulties to adjust to unexpected shifts in the demand for money in order to smooth cyclical fluctuations in economic activity and (c) significant cost of producing money.

\section{Table 3. Properties of Money/MOnetary systems}

Bitcoin Fiat Money Commodity-based systems

$\begin{array}{llll}\text { Intrinsic value } & \text { no } & \text { no } & \text { yes } \\ \text { Limited Supply } & \text { yes } & \text { no } & \text { yes } \\ \text { Risk of deflation } & \text { yes } & \text { no } & \text { yes } \\ \text { Risk of inflation } & \text { no } & \text { yes } & \text { no } \\ \text { Flexibility to adjust } & \text { little } & \text { yes } & \text { little } \\ \text { Lender of last resort } & \text { limited } & \text { ample } & \text { limited } \\ \text { Cost of production } & \text { high (energy) } & \text { low } & \text { high } \\ \text { Seigniorage } & \text { private } & \text { public } & \text { private / public }\end{array}$

Analysts have noted (Bordo and Levine, 2017; James, 2018) that a monetary system based, eventually, on digital currencies is likely to have a built-in risk of deflation. The economic logic is that the 
supply of money may turn too scarce (relative to demand) and this can be a source of deflationary pressures in the economy, as it creates excess demand for money whose counterpart, by Walras's law, is an excess supply of goods (and labor, say unemployment). One of the difficulties of the gold standard, particularly in its gold exchange variety in place from the mid 1920s to the $1930 \mathrm{~s},{ }^{11}$ was its inability to facilitate adjustment in relative prices (real depreciation) in the wake of adverse demand shocks in a world of increasing price and wage rigidity (compared to the situation of the classic gold standard of c.1870-1914). In the early 1930s the countries that did stick longer to the gold standard suffered more protracted recessions that those that abandoned the standard earlier (Solimano, 2019) .

A different situation occurs under fiat-money systems in which the supply of money is not geared to metals such as gold. In this case, the currency can be devalued leaving room for demand-increasing policies that can help the economy to pull-out of a recession or depression.

Regarding the built-in risks of inflation in fiat money systems, this follows from the possibility of over-issuing of money leading to upward pressure on prices. Redish (1993)studies the transition from commodity-based money to fiat money throughout history, noting that this process started as early as the $16^{\text {th }}$ century. Initially notes could be issued by banks but they were, in principle, backed 100 percent by metallic coins. The perils of paper- money is illustrated by the travails of Scottish financier John Law, who in France in 1716, managed to get authorization for the Banque Royale of Paris to issue notes that, in principle, were to be backed by coins and gold. The reality of what actually happened was different and the story is told, in an amusing way, in Galbraith (1990). In fact, the Banque Royale in order to print more and more notes sought the backing of the stocks issued by the Mississippi Company (the Companie d'Occident) directed (in theory) to mine gold in the American state of Louisiana. In turn, gold was to serve as a strong collateral for the Bank Royale in Paris . After a happy start of notes printing and appreciation in the value of the shares of the bank, in 1720, the scheme collapsed. 
The Law's affair involving unbacked notes printing in the Banque Royale/Mississippi Company fiasco led to diminished tolerance, that lasted for several decades, for fractional money systems. However, as memory of the event receded, notes issued by private banks started to sprung again in the second half of the $18^{\text {th }}$ century and more fully in the $19^{\text {th }}$ century. The problem of how to prevent new financial crises to occur came to the fore and a solution was sought through the actions of central banks. Nonetheless, the history of the emergence of these institutions is more complex than a simple uninterested custodian of financial stability in the macro-economy as it is suggested by current idealizations of these institutions.

Several central banks were established as a government-chartered bank, with the purpose of providing (cheap) funding to governments. The oldest central bank is the Sverige Riksbank (Bank of Sweden) created in 1668 followed by the Bank of England founded in 1694. In the 1800s central banks were also established in France, Finland, the Netherland, Austria, Norway, Portugal, Denmark, Portugal, Belgium, Spain, Germany, Japan and Italy. In the $19^{\text {th }}$ century the First and Second Banks of the USA were somewhat similar to a central bank in the modern sense but the Federal Reserve Bank was formally established only in 1913 and the Bank of Canada in 1934 (Capie, Goodhart and Schnadt, 1994). In 1900 there were only 18 central banks in the world. In 1930, there were 34 in 1950: 59 in 1970: 108 and in 1990: 161. Central banks are an institution that really expanded in numbers in the $20^{\text {th }}$ century.

When central banks were created they received government bonds as collateral for loans to government, a feature that made them "structurally" averse to inflation. In fact, price increases would erode the real value of the bonds (and interest payments), the main asset in their balance-sheets. After a while central banks were given the monopoly to create base money, a move that reduced their cost of borrowing. As already mentioned, another rationale for establishing central banks was to reduce the risk of financial failure and liquidity crises in a fractional reserve system. This is a preventive and regulatory function, which in times of acute crisis may require 
the provision of liquidity, giving raise to the role of lender of last resort.

The central bank function of a stalwart of financial stability has the perhaps unintended effect of protecting commercial banks from effective competition (moral hazard syndrome), leading to supranormal profits and the formation of powerful financial elites in capitalism. The key was the centralization of reserves that permitted to reduce their reserve ratio (lower metallic backing of the money supply), a stance favored by commercial banks eager to lend more aggressively and make more profits along the way.

Paper money systems may also lead to very high inflation in certain circumstances such as war, the aftermath of war, periods of internal strife and populism. Historical examples of hyperinflation in the first half of the 1920s include Germany, Hungary, Poland, Soviet Russia following a fiscal crisis of the state, severely weakened by the effects of world war I. These episodes took place in the interregnum between the classic gold standard, suspended at the outbreak of world war I, and the new "gold exchange standard" (in this latter system, international reserves by central could be held in other currencies and not only in gold). In the interim, European countries adopted a fiat-money system that presided high inflation, (the Soviet Union, unlike the capitalist countries of Europe and North America, did not adopt the gold exchange standard). There are more examples of hyperinflation such as Greece in 1949, Zimbabwe in 2009, Venezuela in 2017-18. In all these cases the countries had monetary systems based on fiat money. In February 2018, Venezuela announced the launching of a digital-currency standard around the "petro" (crypto-currency) backed by oil, gold and diamonds. Then, fiat money would be anchored to the Petro in order to stabilize the price level and bring an end to hyperinflation. On July 25, 2018 the government undertook a monetary reform in which a new currency, the "sovereign bolivar" replace the bolivar at a rate of exchange of 100.000 bolivar to 1 sovereign bolivar. Yet, the results of this proposed scheme involving a monetary system of crypto-currency remain to be seen. 
7. Entering the mainstream? Central banks issuing cryptoCURRENCIES

Several central banks from advanced industrial nations are considering to issue their own digital-currency (CBCC, or Central Bank Crypto-currencies) on an experimental basis. This is the case of the Bank of Canada (project Jasper), the Monetary Authority of Singapore (project Ubin) and the People's Bank of China. at the Bank of Canada and at the Monetary authority of Singapore are instances of developing wholesale Central Bank crypto-currencies, (Bech and Garrat, 2017). An important reason for this interest of central banks not to be left outside from the wave of digital currencies stance is that advanced technology of DLT and blockchain offer clear advantages over more traditional technologies of electronic transfers. In addition, central banks have obviously noticed the decline in the demand for cash and its substitution for electronic transfer mechanisms along with the growing acceptance of cryptocurrencies in the market. In this case the supply of digital currency by central banks, CBCC, would lead, probably, to replace the fixed supply rule of bitcoins for a new, more flexible rule, in order to adjust to changes in the demand for money and smooth the business cycle. In addition, this flexibility could be extended to deal with instances of financial destabilization and crises situations-function of lender of last resort --although this would probably require to have an accumulated stock of CBCC to sell to commercial banks. A distinction is made between Central Bank retail digital currencies and wholesale CBCC. The former would be digital currency used by atomistic consumers and retail traders (stores) while wholesale CBCC would be used to make transfers between financial intermediaries. In the case of retail CBCC, the central bank issues a digital currency that would have a one-for-one convertibility with cash and reserves (e.g at an exchange rate of 1 to 1 between the monetary base and digital currency base). Retail blockchains would be open-source (no permissions required to enter in the chain) but wholesale blockchains would require permission. Fedcoins, say a retail cryptocurrency issued by the US Federal Reserve, would be created when 
the supply of cash and reserves increases and destroyed otherwise. Fedcoins would be decentralized in their use but centralized in their supply; in contrast, Bitcoin is decentralized both in supply and use. A similar model to the Fedcoin is the e-krona, a retail crypto-currency to be issued by the Swedish central bank. Sweden is a case of very rapid adoption of electronic payment systems, with more than 50 percent of the population using mobile phone apps to make transactions, with many stores and bank branches no longer accepting cash. This has led to a steady decline in the demand for notes and coins, paving the way for the issuing digital money by the central bank.

In wholesale central bank crypto-currencies the potential advantage of adopting DLT -based software for the issue of digital currencies seem very appealing as existing programs of electronic transfers are based in obsolete languages and outdated data bases. Various technical issues need to be solved for the feasibility of adopting these new schemes. For example, traditional "proof-of work" validation to prevent double-spending in decentralized DLT schemes could be done with the help of a "trusted notary" (e.g the central bank). This procedure is claimed to be less costly in terms of energy-use than decentralized blockchains validation procedures (Bech and Garrat, 2017). Other issues relate to transferring central bank money to the ledger (list of transactions/blockchain) and the implementation of liquidity-saving mechanism on the DLT.

\section{Conclusions}

The emergence of bitcoin at the time of the 2008-09 crisis based on a decentralized software mechanism for secure, peer to peer transactions that do not need validating by intermediaries is an example of practical use of the last wave of technological innovation based in distributed ledgers. The inception of digital currencies is still in an early stage and may be too premature to pass defining evaluation on its present and future. The market value of cryptocurrencies has grown substantially but bitcoin is still far from replacing conventional currencies. So far, its main impact lies in showing that 
a decentralized currency is feasible based on new technologies. This paper presents empirical evidence on the behavior of the price of bitcoin in the period 2010-2018, showing sharp rises in mean price values but accompanied also by substantial volatility. The stochastic behavior of bitcoin prices seems to display the pattern of a bubble, already observed in other episodes in financial history. The paper also points that digital currencies have non-trivial cost of production (energy and blockchain mining costs) and its fixed supply rule may lead to a deflationary bias in a growing economy. On the other hand, an indication of the potential of digital currencies lies in the fact that central banks of main industrial countries are considering launching on an experimental basis digital currencies. In turn, some high-inflation economies are seeking to stabilize prices through pegging fiat money to a crypto-currency standard.

\section{REFERENCES}

ADRIANO, A. (2018) "A Short history of Crypto Euphoria" Finance \& Development, June, Vol. 55, \# 2.

BIS-CPMI (2015) Digital Currencies, A Report by the Committee on Payments and Market Infrastructures, Bank for International Settlements, Geneva.

BECH, M. and R.Garratt (2017) "Central Bank Crypto-currencies" BIS Quarterly Review, September.

BORDO, M. and A. Levin (2017) "Central Bank Digital Currency and the Future of Monetary Policy" mimeo.

CAPIE, F; C. Goodhart, C. and N. Schnadt, (1994) "The development of central banking" in Capie, F; S. Fischer, C. Goodhart, C. and N. Schnadt, editors, The future of central banking: the tercentary symposium of the Bank of England. Cambridge, UK: Cambridge University Press.

FOLEY, S., J.K. Karlsen and T.J. Putnins (2018) "Sex, Drugs, and bitcoin: how much illegal activity is financed through cryptocurrencies? Manuscript, University of Sydney, University of Technology of Sydney and Stockholm School of Economics in Riga. 
GALBRAITH, J.K. (1990) A Short History of Financial Euphoria, Penguin Books.

HE, D. (2018) "Monetary Policy in the Digital Age" in Finance and Development, June 2018.

IMF (2018) Global Financial Stability Report, Washington DC. JAMES, H. (2018) “ Lucre's Allure” in Finance \& Development, June, Vol. 55, \# 2.

REDISH, A. (1993) "Anchors Aweigh: The Transition from Commodity Money to Fiat Money in Western Economies" The Canadian Journal of Economics, Vol. 26, \# 4 (November), pp. 777-795.

SCHERBINA, A. (2013) "Asset Price Bubbles: A Selective Survey" IMF Working Papers No. 13/45

SELGIN, G. (2015) "Synthetic Commodity Money" Journal of Financial Stability, 17, pp. 92-99.

SOLIMANO, A. (2018) Global Capitalism in Disarray, Inequality, Debt and Austerity. Oxford University Press.

(2019) A History of Big Recessions in the Long 20 th Century, Cambridge University Press (forthcoming).

STIGLITZ, J. (1990) "A symposium on bubbles". Journal of Economic Perspectives; Volume 4, Number 2, p13-18.

WEB, W.E. (2016) "A Bitcoin Standard: Lessons from the Gold Standard" Bank of Canada Staff Working Paper 2016-14.

\section{Notas de Página}

${ }^{1}$ Encryption features can be activated and deactivated by the use of public and private keys held by anonymous participants.

${ }^{2}$ The Franciscan friar Luca Pacioli, also a mathematician, devised in 1494 the accounting double-entry system that provided an enormous impetus to the development of trade and finance.

${ }^{3}$ The status of legal tender of central bank money, in principle, ensures trust and credibility, although this feature can be undermined in a highly inflationary environment.

${ }^{4}$ The fundamental value of a stock is the expected stream of 
future dividends discounted at a certain interest rate. In turn, the fundamental value of a house would be the expected future rents that owning a house entails, again discounted at a certain rate. See Scherbina, (2013) and Stiglitz, (1990).

${ }^{5}$ See Adriano (2018) for some elaboration on this.

${ }^{6}$ The common practice of central banks worldwide is not to allow individual accounts for the monetary base (notes and coins) although money base is an entry into the liabilities of the central bank. See He (2018).

${ }^{7}$ Central banks back base-money (cash plus reserves) in centralized monetary systems and ensure, with the help of financial regulators, the soundness of commercial banks to ensure the payment system works properly. See BIS (2015).

${ }^{8}$ In Europe since the 1200s, coins were legal tender for a given unit of account values. Coins were defined by metals (gold, silver, copper), fineness (carat gold or sterling silver) and weight, (Redish, 1993).

'Gresham's law predicts that money that is undervalued -its market price is higher than the nominal value of the currency (coins) - is good money but it will be driven- out of circulation (to economize on its use since it is too valuable) or will circulate at a premium. The typical adjustment to this situation is through rising the legal tender value of the undervalued metal.

${ }^{10} \mathrm{~A}$ similar idea is presented in Selgin (2015).

${ }^{11}$ Various countries abandoned the gold standard at different times in the 1930s: Britain in 1931, the US in 1933 and France in 1936, see Solimano, 2019.

Fecha de Recepción del Artículo: 6 de Agosto de 2018 Fecha de Aceptación: 10 de Agosto de 2018 